\title{
1 Using bar preservation to constrain reworking in channel-dominated fluvial
}

\section{2 stratigraphy}

3 Ellen P. Chamberlin ${ }^{1}$ and Elizabeth A. Hajek ${ }^{1}$

$4{ }^{1}$ Department of Geosciences, The Pennsylvania State University, 511 Deike Building, University Park,

5 Pennsylvania 16802, USA

6

Note: This is a pre-print manuscript that has been submitted to Geology. The published version of this

manuscript may be significantly revised. Please feel free to contact the authors; feedback is welcome.

\section{ABSTRACT}

11 Fluvial deposits comprising more than $80 \%$ channel facies are often thought to have accumulated during

12 intervals of relatively slow subsidence in sedimentary basins. This interpretation stems from the

13 conceptual model that migrating and avulsing rivers rework their own deposits during times of limited

14 accommodation creation, preferentially removing and bypassing fine floodplain deposits. Alternatively,

15 channel-dominated stratigraphy may reflect avulsion patterns that favor channel preservation over

16 floodplain preservation, or channel networks fed by sand-rich sediment sources that never deposited

17 significant floodplain sediments. These potential origins of channel-dominated stratigraphy cannot be

18 differentiated without a way of independently assessing how ancient rivers eroded and reworked their

19 own alluvium. Here we propose a new method that uses fluvial-bar preservation as a proxy for reworking

20 in channel-dominated stratigraphy. We apply this approach to the lower Castlegate Sandstone (Upper

21 Cretaceous, Utah, USA) and use geometric modeling to investigate the degree to which sediment supply

22 and avulsion dynamics influence fluvial deposit preservation. Castlegate exposures in central Utah show

23 up to $80 \%$ bar preservation in some localities, suggesting that, in contrast to previously published

24 interpretations, Castlegate channel deposits are not heavily reworked and accommodation-creation rates

25 during Castlegate deposition might have been relatively high. Model comparisons indicate that well- 
preserved Castlegate deposits could have resulted from random avulsions in a rapidly aggrading basin with a sand-dominated sediment supply, or under lower aggradation conditions if river avulsions avoided previously occupied locations. This approach represents a new advance for interpreting the relationships between basin accommodation, sediment supply, and avulsion dynamics on ancient landscapes and provides a new method for estimating sediment reworking and bypass from ancient river deposits.

\section{INTRODUCTION}

The stratigraphic arrangement of channel and floodplain deposits is controlled by the balance of accommodation creation and sediment supply in a basin, and by river dynamics like channel migration and avulsion (e.g., Leeder, 1978; Straub and Esposito, 2013). In principle, the architecture of fluvial basin fills can be inverted to reconstruct these controls; however, in practice, it can be difficult to uniquely interpret the balance of subsidence, sediment supply, and channel dynamics from channel and floodplain deposits in a basin fill (Hajek et al., 2012).

In basins that subside relatively slowly, channels can migrate and avulse across the land surface quickly relative to the time it takes to bury sediments below a characteristic channel depth (e.g., Paola and Borgman, 1991; Straub and Esposito, 2013; Wickert et al., 2013). Until this burial occurs, deposits are

41 subject to erosion and reworking by the active channel network, which can result in extensive, amalgamated channel deposits (e.g., Allen, 1978; Bridge and Leeder, 1979; Leeder, 1978). Consequently, channel-dominated fluvial deposits are often interpreted as indicating times of relatively slow accommodation-creation in alluvial basins (e.g., Miall and Arush, 2001; Shanley and McCabe, 1994; Wright and Marriott, 1993). relationship with accommodation-creation rate (Colombera et al., 2015), which suggests that other factors significantly influence fluvial stratigraphic architecture. For example, under the same sediment-supply and subsidence rates, a deep river system should produce more heavily reworked, amalgamated deposits than a shallower river network (e.g., Hajek and Heller, 2012; Straub and Esposito, 2013), and deposits

51 from rivers that migrate quickly or avulse frequently should be more heavily reworked than deposits from 
less mobile rivers, all else being equal (e.g., Bristow and Best, 1993; Heller and Paola, 1996; Straub and Esposito, 2013; Wickert et al., 2013). Furthermore, modeling has shown that avulsion patterns influence channel-deposit preservation; if channels preferentially avulse to previously occupied locations, channel deposits are more poorly preserved than deposits of channels that avulse randomly or preferentially to basin lows (i.e., compensation; Chamberlin and Hajek, 2015). Finally, channels in basins supplied with a large amount of sand relative to mud may be wide and mobile, resulting in limited floodplain deposition even if basin-wide sedimentation rates are high. All of these scenarios can produce channel-dominated and we apply this method to deposits of the lower Castlegate Sandstone (Campanian, Utah, USA), a wellstudied channel-dominated fluvial deposit that has previously been interpreted as having formed during an interval of relatively low accommodation creation (e.g., Miall and Arush, 2001; Van Wagoner, 1995). We found two Castlegate localities with remarkably high bar preservation, suggesting that in some regions Castlegate rivers were not significantly reworking their own deposits. We explore these results using a geometric model to evaluate how channel-deposit preservation reflects basin aggradation, channel avulsion pattern, and the ratio of channel and overbank sediment supplied to a system. ESTIMATING FLUVIAL BAR PRESERVATION IN THE CASTLEGATE SANDSTONE height of the free surface of the channel flow (e.g., Mohrig et al., 2000). Migrating bars produce clinoform surfaces which, when fully preserved, have a sigmoidal shape (Figure 1; e.g., Hajek and Heller, 2012; Miall, 1994; Mohrig et al., 2000). Bar deposits generally fine upwards and exhibit predictable changes in sedimentary structures (e.g., from dune-scale trough cross-bedding near the base to ripplescale cross-beds at the bar top; Miall, 1994). Although specific bar clinoform geometries and facies characteristics vary from river to river, the general trend of broadly sigmoidal clinoform geometries and 
We defined three broad categories of bar preservation based on observable bar-clinoform geometries and facies successions (Figure 1D). Fully preserved bar deposits have clinoform sets with bartop rollover and upper-bar lithofacies. Partially preserved bar deposits may show minor top truncation

81 (i.e., no observable bar-top rollover) but contain upper-bar lithofacies. Poorly preserved bars show no bar82 top rollover, only contain lower-bar lithofacies, and may be directly truncated by a scour surface. For this 83 study, we focused on characterizing preservation of bars underlying avulsion-generated channel-belt 84 surfaces (c.f., Chamberlin and Hajek, 2015). We mapped bar preservation in three well-exposed 85 Castlegate localities in central Utah using a combination of detailed field observations, high-resolution photo panoramas, and laser-generated 3D outcrop models (Figure 1; Supplement).

\section{Results and Interpretation}

Castlegate bar preservation varies significantly by location; the majority of bars mapped in the Price and Salina localities are fully preserved, but $79 \%$ of bars at Joe's Valley are poorly preserved (Table 1, Figure 1). Well preserved deposits at Price and Salina suggest that the accommodation-creation rate must have been sufficiently high to regularly preserve complete packages of bar sediment. This contrasts with previous interpretations of these outcrops, which assume that rapid reworking in a lowaccommodation setting caused the high proportion of channel deposits relative to floodplain deposits (e.g., Miall and Arush, 2001; Van Wagoner, 1995), but is consistent with the idea that sand-rich fluvial deposits do not necessarily reflect low long-term sedimentation rates (e.g., Colombera et al., 2015).

\section{MODELING AVULSION CONTROLS ON REWORKING}

We used a 2D rule-based model of basin filling (Chamberlin and Hajek, 2015) to understand how avulsion dynamics, sediment supply, and aggradation rate can influence channel deposit preservation. At each timestep a channel element is placed at the lowest point in the model domain for compensational avulsion patterns and at a location drawn from a uniform random distribution for random avulsion patterns. To mimic differences in net sediment accumulation and the percentage of sand and mud supplied to a basin, we varied channel incision (as a fraction of channel-element thickness) and the input ratio of 
overbank and channel sediment. We used parameters that created stratigraphy comprising $\geq 80 \%$ channel

104 deposits (Supplement).

105 We analyzed model panels scaled proportionally to Castlegate outcrop exposures (12 channel106 elements-thick x 3 channel-elements-wide with $>30$ individual channel bodies). We categorized channel

107 elements as well preserved if any portion of the channel element retained its original thickness and at least

$10850 \%$ of the channel element area was preserved; remaining elements were classified as poorly preserved.

109 We expected that channel deposit preservation should be high when channel incision was low, overbank

110 sedimentation was high (resulting in high basin-wide sedimentation rates), and avulsion pattern was

111 compensational (preferentially avoiding previous channel deposits). We also tested the null hypothesis

112 that there is a direct linear relationship between total sediment retention (the fraction of supplied sediment

113 retained in the final cross-section) and channel preservation for all incision rates, sediment supply inputs,

114 and avulsion patterns.

115 Results

116 In general, our model results show a direct relationship between channel-element preservation

117 and total sediment retention (Figure 2). This is a useful result in that it suggests, to a first order, that

118 locally observed channel preservation may be a proxy for basin-scale sediment retention or bypass.

119 However, avulsion pattern influences whether channel preservation under- or over-predicts sediment

120 retention. All model runs with random avulsion patterns and compensational model runs with low

121 overbank sediment input fall near or below the 1:1 line, indicating that the percent of well-preserved

122 channel elements approximates or under-predicts sediment retention in the basin. In contrast,

123 compensational model runs with higher overbank input over-predict total sediment retention. This occurs

124 because compensational avulsions preferentially remove overbank sediments and preserve channel

125 elements.

126 DISCUSSION

127 The range of channel-element preservation observed in our model stratigraphy captures the range 128 of bar preservation observed in the Castlegate Sandstone (Figure 2). Joe's Valley compares with models 
130 occurred in that locality. In contrast, Salina is consistent with models that retained $50-80 \%$ of the input

131 sediment, indicating much higher sediment storage in that portion of the basin. The high proportion of

132 well-preserved bars observed in Price corresponds to two distinct groups of model runs: 1) runs with low

133 amounts of overbank sediment input and low channel incision, or 2) higher amounts of overbank

134 sediment input, higher channel incision and compensational avulsion patterns. Even in the models with

135 relatively high supplies of mud, the resulting stratigraphy was both channel-dominated and well preserved

136 because the compensational avulsion pattern caused floodplain deposits to be preferentially removed.

137 Regional subsidence gradients along the Sevier thrust front during Castlegate deposition (Pang

138 and Nummedal, 1995) are not large enough explain the difference in preservation between Castlegate

139 localities. However, the poor preservation at Joe's Valley is consistent with deeper channels in this

140 locality (Table). Furthermore, Joe's Valley might have been situated near the apex of a fluvial fan system;

141 these proximal regions are often relatively narrow, so migrating and avulsing channels more frequently

142 occupy each area of the fan surface resulting in higher rates of reworking (e.g., Owen et al., 2015). In

143 contrast, bar preservation at Salina and Price indicate that deposition rates in this portion of the basin were

144 high relative to how quickly channels migrated across their alluvial plains. Because the overall character 145 of preserved bar deposits in each locality is similar, the channel-migration dynamics may have been 146 comparable, suggesting that the higher degree of reworking in Joe's Valley may have been primarily 147 caused by deeper channels moving across a narrower alluvial plain. In contrast, the exceptionally high 148 preservation rates of bars in Price could have been caused by a sand-dominated sediment supply or a 149 channel network that avulsed compensationally across a broad alluvial plain. Collectively, our field 150 observations and modeling indicate that the dynamics of Castlegate sediment-transport networks were 151 important controls on Castlegate stratigraphy.

152 Differences in Castlegate bar preservation have broader implications for interpreting sediment 153 storage and bypass in fluvial landscapes and for predicting reservoir connectivity in channel-dominated 154 deposits. Model results suggest that systems dominated by compensational avulsions preferentially 
155 bypass fine-grained sediment. In this scenario, counter to what is predicted by many sequence156 stratigraphic models, coarse sediment would be retained in upstream reaches and channel-dominated

157 fluvial deposits would not correlate to system-wide progradation of course sediment. Compensational 158 avulsions may therefore enhance downstream fining along fluvial profiles. Furthermore, despite the 159 abundance of sands, channel-dominated deposits may not be internally well connected if they were 160 produced by a fluvial system with muddy sediment supply and compensational avulsion patterns, because 161 pockets of fine sediment might be retained within bars and channel bodies (e.g., Lynds and Hajek, 2006).

\section{CONCLUSIONS}

We presented a new method that uses bar preservation as a proxy for reworking in channel-

164 dominated fluvial deposits. This broadly applicable approach can be used to uniquely identify channel-

165 dominated stratigraphy that reflects rapid channel migration and avulsion relative to long-term deposition 166 rates. Analysis of bar preservation at three sites in the lower Castlegate Sandstone shows that the majority

167 of bars at two sites are well preserved, suggesting that lower Castlegate rivers did not significantly rework

168 their alluvium in these locations. This result contrasts with classic interpretations of the Castlegate

169 Sandstone as a reworked sand sheet deposited during a period of relatively low accommodation-creation

170 rates. Results of this study emphasize that channel-dominated fluvial deposits are not robust indicators of

171 low accommodation and significant reworking and highlights how river dynamics can be an important

172 control on the preservation of fluvial deposits.

173

174

175

176

177

\section{ACKNOWLEDGEMENTS}

This work was supported by National Science Foundation grants 1024443 and 1455240 to Hajek and Geological Society of America Graduate Research Grants to Chamberlin. We thank A. Lesko, F.

Chamberlin, S. Trampush, A. Franklin, and E. Greenburg for assistance in the field. 


\section{REFERENCES}

Allen, J. R. L., 1978, Studies in fluviatile sedimentation: an exploratory quantitative model for the architecture of avulsion-controlled alluvial suites: Sedimentary Geology, v. 21, p. 129-147.

Bridge, J. S., and Leeder, M. R., 1979, A simulation model of alluvial stratigraphy: Sedimentology, v. 26, p. 617-644.

Bristow, S., and Best, J., 1993, Braided rivers: perspectives and problems: Geological Society Special Publication, v. 75, p. 1-11.

Chamberlin, E. P., and Hajek, E. A., 2015, Interpreting Paleo-Avulsion Dynamics from Multistory Sand Bodies: Journal of Sedimentary Research, v. 85, no. 2, p. 82-94.

Colombera, L., Mountney, N. P., and McCaffrey, W. D., 2015, A meta-study of relationships between fluvial channel-body stacking pattern and aggradation rate: Implications for sequence stratigraphy: Geology, v. 43, no. 4, p. 283-286.

Hajek, E. A., and Heller, P. L., 2012, Flow-depth scaling in alluvial architecture and nonmarine sequence stratigraphy: example from the Castlegate Sandstone, Central Utah, U.S.A: Journal of Sedimentary Research, v. 82, no. 2, p. 121-130.

Hajek, E. A., Heller, P. L., and Schur, E. L., 2012, Field test of autogenic control on alluvial stratigraphy (Ferris Formation, Upper Cretaceous-Paleogene, Wyoming): Geological Society of America Bulletin, v. 124, no. 11-12, p. 1898-1912.

Heller, P. L., and Paola, C., 1996, Downstream changes in alluvial architecture: an exploration of controls on channel-stacking patterns: Journal of Sedimentary Research, v. 66, no. 2, p. 297-306.

Leeder, M. R., 1978, A quantitative stratigraphic model for alluvium, with special reference to channel deposit density and interconnectedness, in Miall, A. D., ed., Fluvial Sedimentology: Calgary, Canadian Society of Petroleum Geologists, Memoir 5, p. 587-596.

Miall, A., 1994, Reconstructing fluvial macroform architecture from two-dimensional outcrops: examples from the Castlegate Sandstone, Book Cliffs, Utah: Journal of Sedimentary Research, v. 64, no. 2, p. $146-158$.

Miall, A. D., and Arush, M., 2001, The Castlegate Sandstone of the Book Cliffs, Utah: Sequence Stratigraphy, Paleogeography, and Tectonic Controls: Journal of Sedimentary Research, v. 71, no. 4, p. 537-548.

Mohrig, D., Heller, P. L., Paola, C., and Lyons, W. J., 2000, Interpreting avulsion process in ancient alluvial sequences: Guadalope-Matarranya system (northern Spain) and Wasatch Formation (western CO): Geological Society of America Bulletin, v. 112, p. 1787-1803.

Owen, A., Nichols, G. J., Hartley, A. J., Weissmann, G. S., and Scuderi, L. A., 2015, Quantification of a Distributive Fluvial System: The Salt Wash DFS of the Morrison Formation, SW U.S.A: Journal of Sedimentary Research, v. 85, no. 5, p. 544-561.

Pang, M., and Nummedal, D., 1995, Flexural subsidence and basement tectonics of the Cretaceous Western Interior basin, United States: Geology, v. 23, no. 2, p. 173-176.

Paola, C., and Borgman, L., 1991, Reconstructing random topography from preserved stratification: Sedimentology, v. 38, no. 4, p. 553-565.

Shanley, K. W., and McCabe, P. J., 1994, Perspectives on the Sequence Stratigraphy of Continental Strata: AAPG Bulletin, v. 78, p. 544-568.

Straub, K. M., and Esposito, C. R., 2013, Influence of water and sediment supply on the stratigraphic record of alluvial fans and deltas: Process controls on stratigraphic completeness: Journal of Geophysical Research: Earth Surface, v. 118, no. 2, p. 625-637.

Van Wagoner, J. C., 1995, Sequence stratigraphy and marine to nonmarine facies architecture of foreland basin strata, Book Cliffs, Utah, U.S.A., in Van Wagoner, J. C., and Bertram, G. T., eds., Sequence Stratigraphy of Foreland Basin Deposits: Outcrop and Subsurface Examples from Cretaceous of North America, American Association of Petroleum Geologists, Memoir 64, p. 137-223. 
Wickert, A. D., Martin, J. M., Tal, M., Kim, W., Sheets, B., and Paola, C., 2013, River channel lateral mobility: metrics, time scales, and controls: Journal of Geophysical Research: Earth Surface, v. 118, no. 2, p. 396-412.

\section{FIGURE CAPTIONS}

Figure 1: (A-C) Study area and field data from the lower Castlegate Sandstone; localities indicated on map, upper right. Top image for each locality is an uninterpreted photo-panel with an interpreted panel below. Colors show interpreted lithofacies (yellow $=$ lower bar; green $=$ upper bar; gray = overbank). Solid black lines are channel-belt scours and dashed black lines are internal (intra-channel-belt) scour surfaces. Colored lines show bar co-sets categorized by preservation (blue - fully preserved; light blue partially preserved; red - poorly preserved. D) Conceptual example of bar mapping (top) and close-up example of bar facies and preservation interpretations from a Price outcrop example (bottom; example

Figure 2: Model results showing percent of channel elements that are well preserved versus total sediment retention (percent of sediment input remaining in output cross-section) per model run. Points are colored by the ratio of overbank to channel sediment input, where higher values have higher overbank input. Random avulsion outputs are triangles, and compensational outputs are circles. Dashed lines show the percent of well preserved bars from each lower Castlegate Sandstone field locality (see Table 1 for complete field data). Inset A is an example of part of a model output from a random avulsion run with low overbank input (data point shown in square box), where well preserved rectangular channel elements are dark gray and poorly preserved channels are light gray (see Figure DR3-DR4 for more detail). 
A. Price Canyon Mean paleoflow depth: $2.6 \mathrm{~m}$; mean bar-package width: $58 \mathrm{~m}$ $5 \mathrm{~m}$

B. Joe's Valley Mean paleoflow depth: $3.6 \mathrm{~m}$; mean bar-package width: $180 \mathrm{~m}$

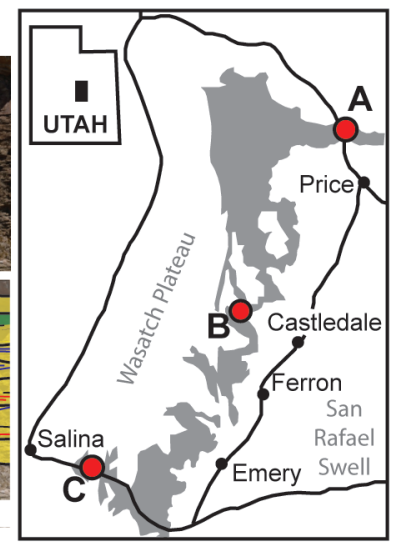

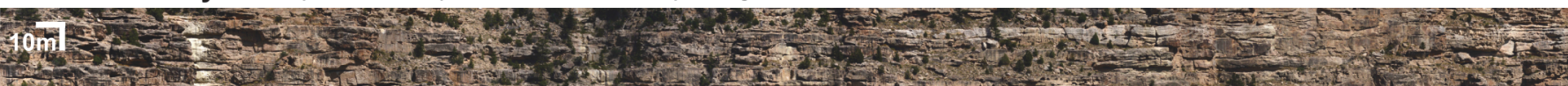

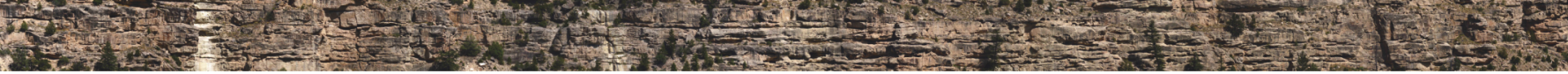

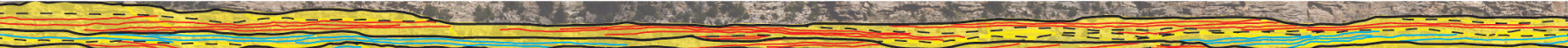

C. Salina Canyon Mean paleoflow depth: 3.9 m; mean bar-package width: $87 \mathrm{~m}$ $5 \mathrm{~m}$

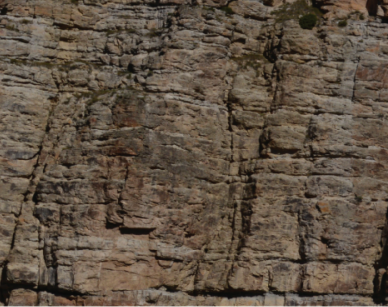

D. Bar Mapping Example

- - Bar surface

Channel-belt surface

Partially preserved

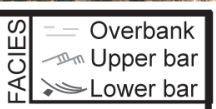
Fully preserved

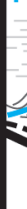

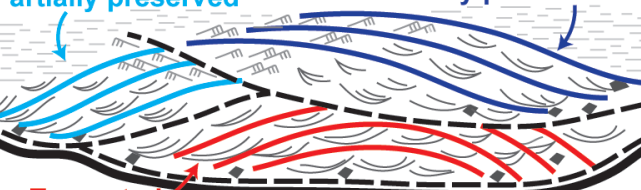

Truncated

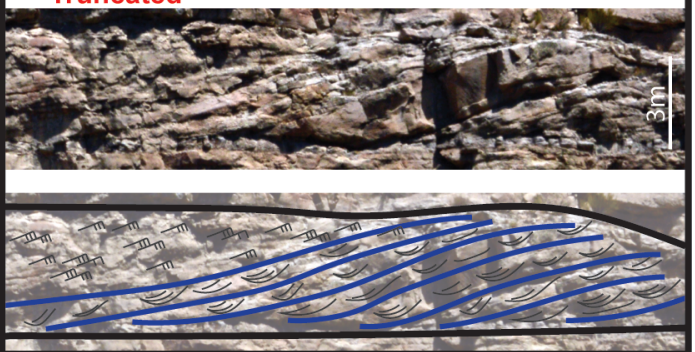




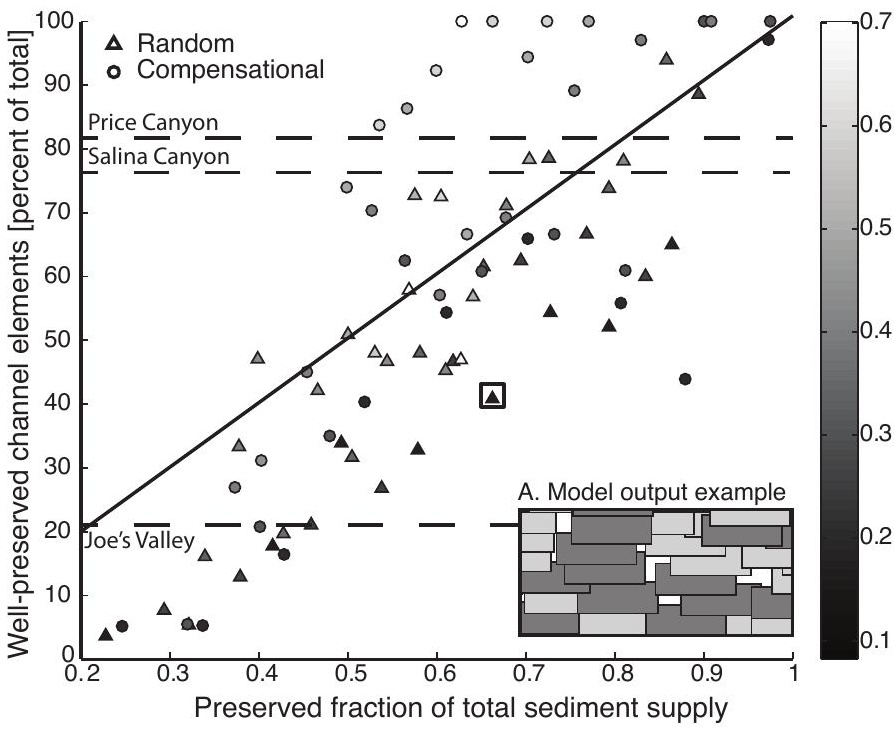


TABLE 1. BAR PRESERVATION RESULTS OF EACH FIELD SITE

\begin{tabular}{|c|c|c|c|c|c|c|c|c|c|}
\hline \multirow[t]{3}{*}{ Site } & \multirow[t]{3}{*}{$\begin{array}{l}\text { Paleoflow } \\
\text { depth }(m)\end{array}$} & \multicolumn{8}{|c|}{$\begin{array}{c}\text { Bar preservation } \\
\text { (\% of total) }\end{array}$} \\
\hline & & \multicolumn{4}{|c|}{ Channel-belt truncated $^{*}$} & \multicolumn{4}{|c|}{ All bars ${ }^{\#}$} \\
\hline & & Full & Partial & Poor & $\mathrm{N}$ & Full & Partial & Poor & $\mathrm{N}$ \\
\hline Price Canyon & 2.6 & 66 & 16 & 19 & 32 & 50 & 14 & 36 & 50 \\
\hline Joe's Valley & 3.6 & 0 & 21 & 79 & 14 & 0 & 18 & 81 & 23 \\
\hline Salina Canyon & 3.9 & 59 & 18 & 24 & 17 & 35 & 35 & 29 & 34 \\
\hline
\end{tabular}




\section{Chamberlin and Hajek}

\section{SUPPLEMENTAL INFORMATION}

\section{DATA FROM THE CASTLEGATE SANDSTONE}

\section{Site selection}

Bar preservation was classified in three outcrop panels in the lower Castlegate Sandstone along the Wasatch Plateau (Figure 1 and Figure DR1). The outcrops used in this study are oblique to paleoflow direction, and flow direction of individual bars can vary widely; paleoflow at Price and Joe's Valley was east-southeast (Robinson and Slingerland, 1998), and southeast at Salina (Chamberlin, 2016). The analyzed outcrop panels are at least three times the observed average bar width and eight times measured average paleoflow depths.

Gigapans (high resolution photo panoramas) for each panel are available online at the following locations:

1) Price Canyon panel: http://www.gigapan.com/gigapans/181311

2) Joe's Valley: http://www.gigapan.com/gigapans/177202

3) Salina Canyon: http://www.gigapan.com/gigapans/175868

Terrestrial lidar datasets of the Price and Salina Canyon panels are available from the authors.

Figure DR1 (next pages): Castlegate outcrop panel locations (yellow) shown on Google Earth images. Polygons are available as a KML file at the following location:

https://sites.google.com/a/denison.edu/supplement chamberlin hajek/. Blue arrows show published mean paleocurrent directions for Price $\left(\mathrm{A} ; 102.9^{\circ}\right)$ and Joe's Valley $\left(\mathrm{B} ; 127.5^{\circ}\right)$ (Robinson and Slingerland, 1998). Authors' mean paleocurrent direction is shown for Salina $\left(C ; 132^{\circ}\right)$, which contrasts with previously published measurements from Adams and Bhattacharya (2005) that show a southwest mean paleocurrent direction in the same area. 
A. Price Panel location near the type section at Castle Gate.

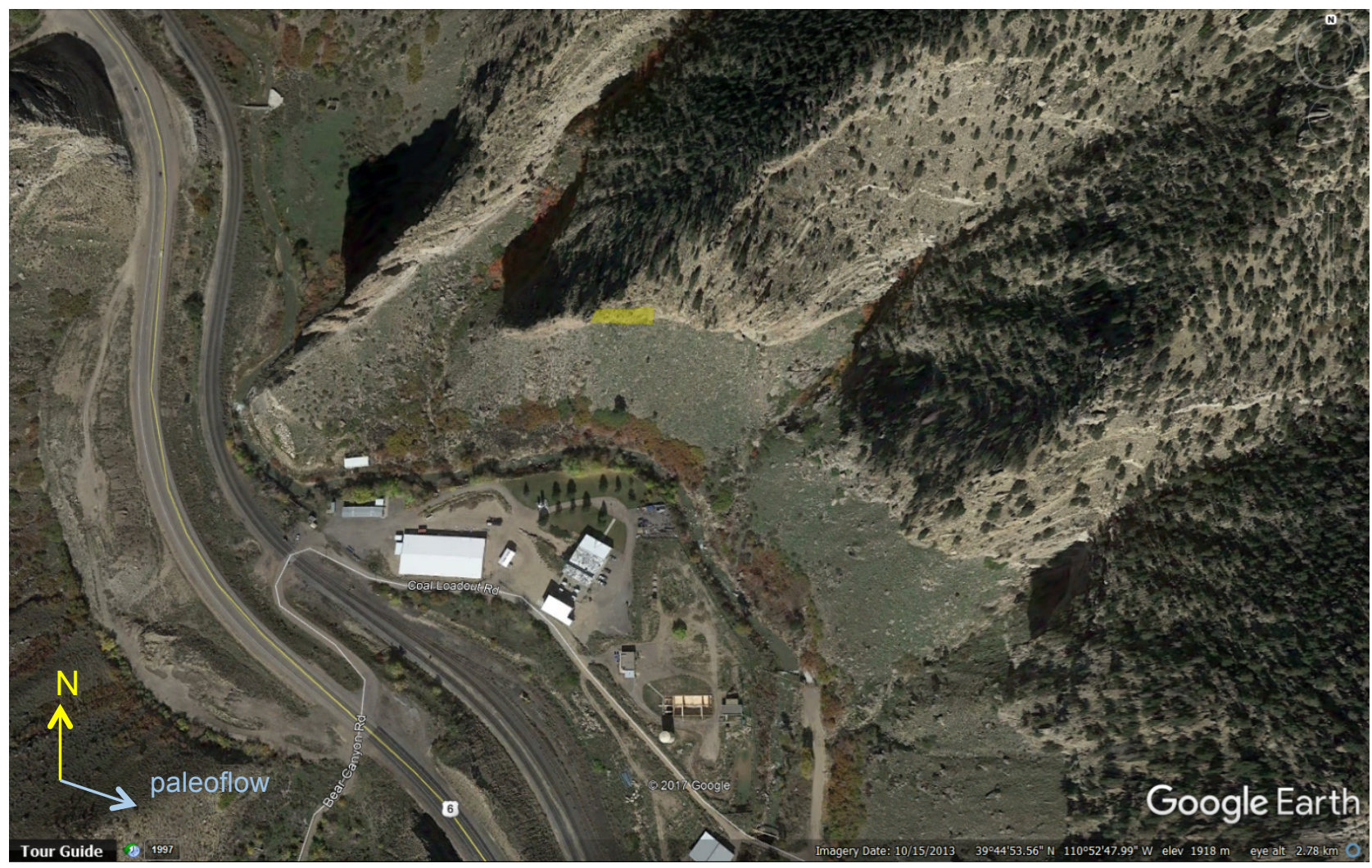

B. Joe's Valley panel location along the road bordering the reservoir.

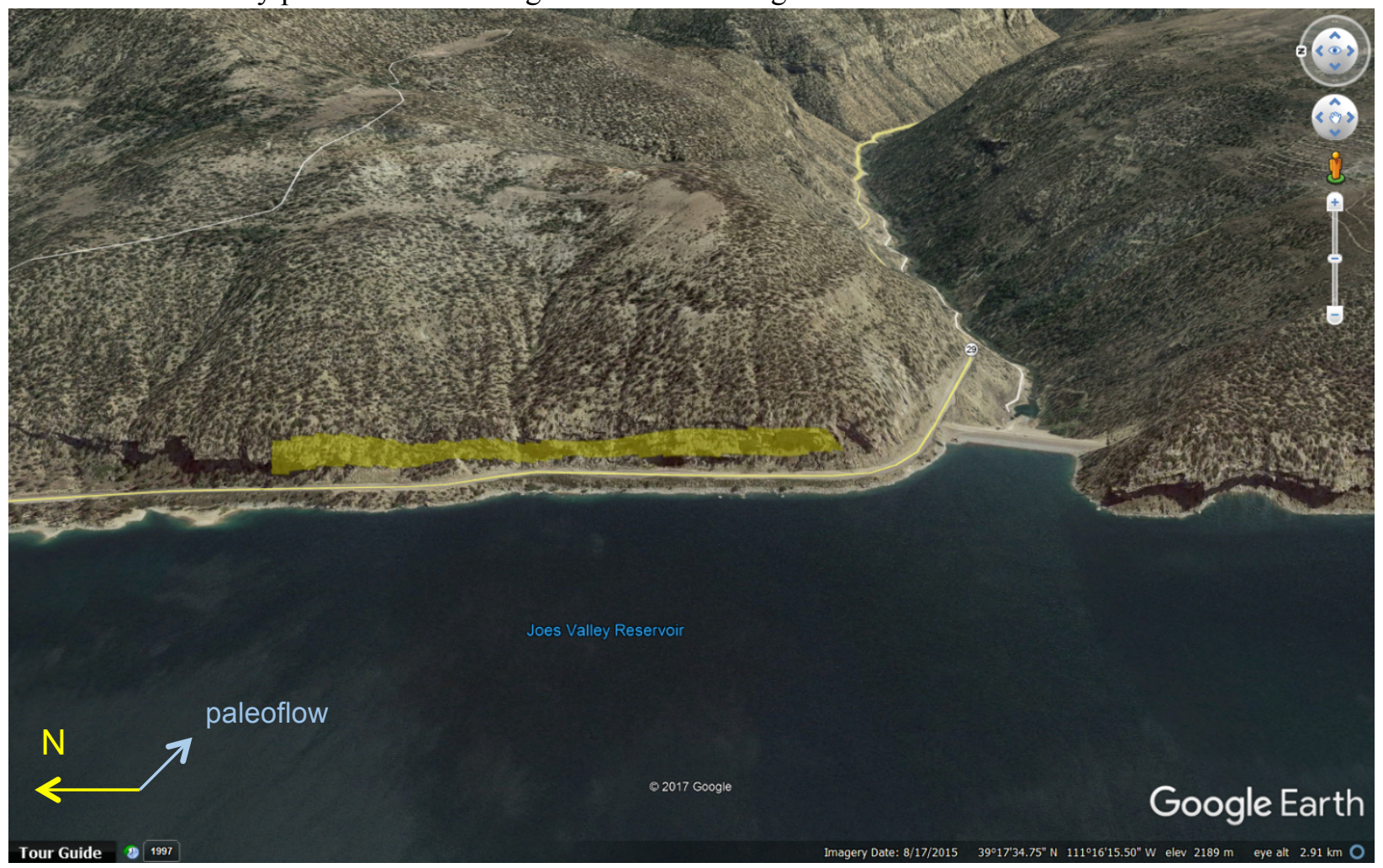


C. Salina Canyon panel location along Water Hollow Road.

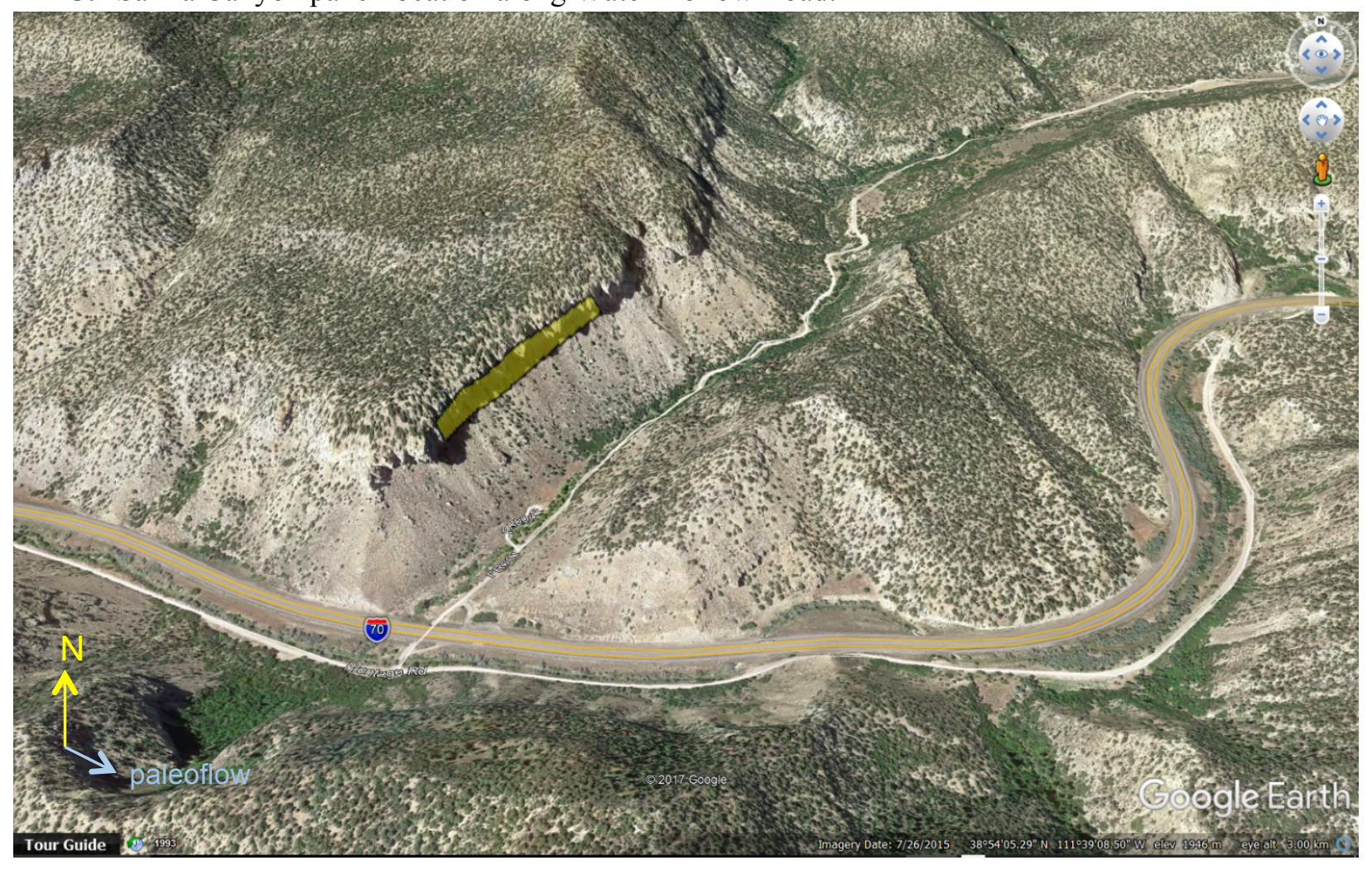




\section{Mapping bar preservation}

We used a combination of detailed field observations, Gigapans (high resolution photo panoramas), and terrestrial lidar (laser-generated 3D outcrop models) to evaluate bar preservation at each site. Figures DR2

- DR4 on the following pages show high-resolution, enlarged versions of each mapped panel.

To categorize bar preservation at each outcrop, we began with using field observations, measured sections, and high-resolution imagery to map lithofacies and scour surfaces on the outcrop panels. Table DR1 contains summary lithofacies descriptions at each site. To separate the effects of channel avulsion from intra-channel-belt dynamics, we categorized scour surfaces as channel-belt or intra-channel-belt, following Chamberlin and Hajek (2015). Channel belt scours were laterally extensive and were stratal termination surfaces for smaller-scale scours; these are approximately equivalent to the SRS 7-scale surfaces of Miall (2014). Intra-channel-belt scours had limited lateral extent, terminated against other intra-channel-belt scours or channel-belt scours, and often had smaller vertical relief.

These lithofacies and scour surface maps become the basis for mapping bar surfaces and interpreting bar cosets. Bar clinoform sets were identified as successive $(\geq 3)$ clinothem packages that have similar dip, geometry, thickness, and facies characteristics. We identified bar packages as inclined, sigmoidal, or dome-shaped clinoforms within channel/bar facies that shared dip directions and stratal termination surfaces (e.g., onlap, downlap, or truncation). Finally, we categorized each bar coset as fully, partially, or poorly preserved based on the geometry and lithofacies criteria defined in the manuscript. After interpreting the preservation of each bar coset, we identified bars that directly underlie channel-belt scours, because these large-scale scours are driving the landscape reworking at the stratigraphic architecture scale. 


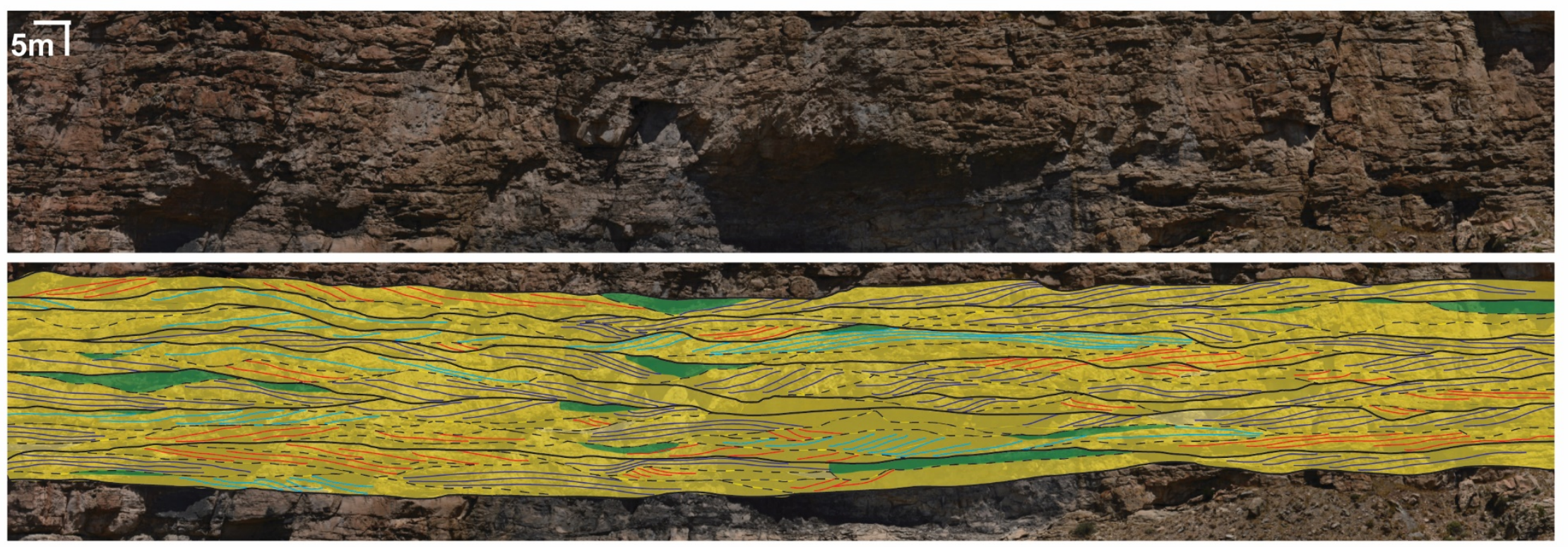

Figure DR2: Enlarged panel of lithofacies and bar preservation from Price Canyon. The panel is oriented east-west (Figure DR1a). See manuscript Figure 2 for key and explanation. 

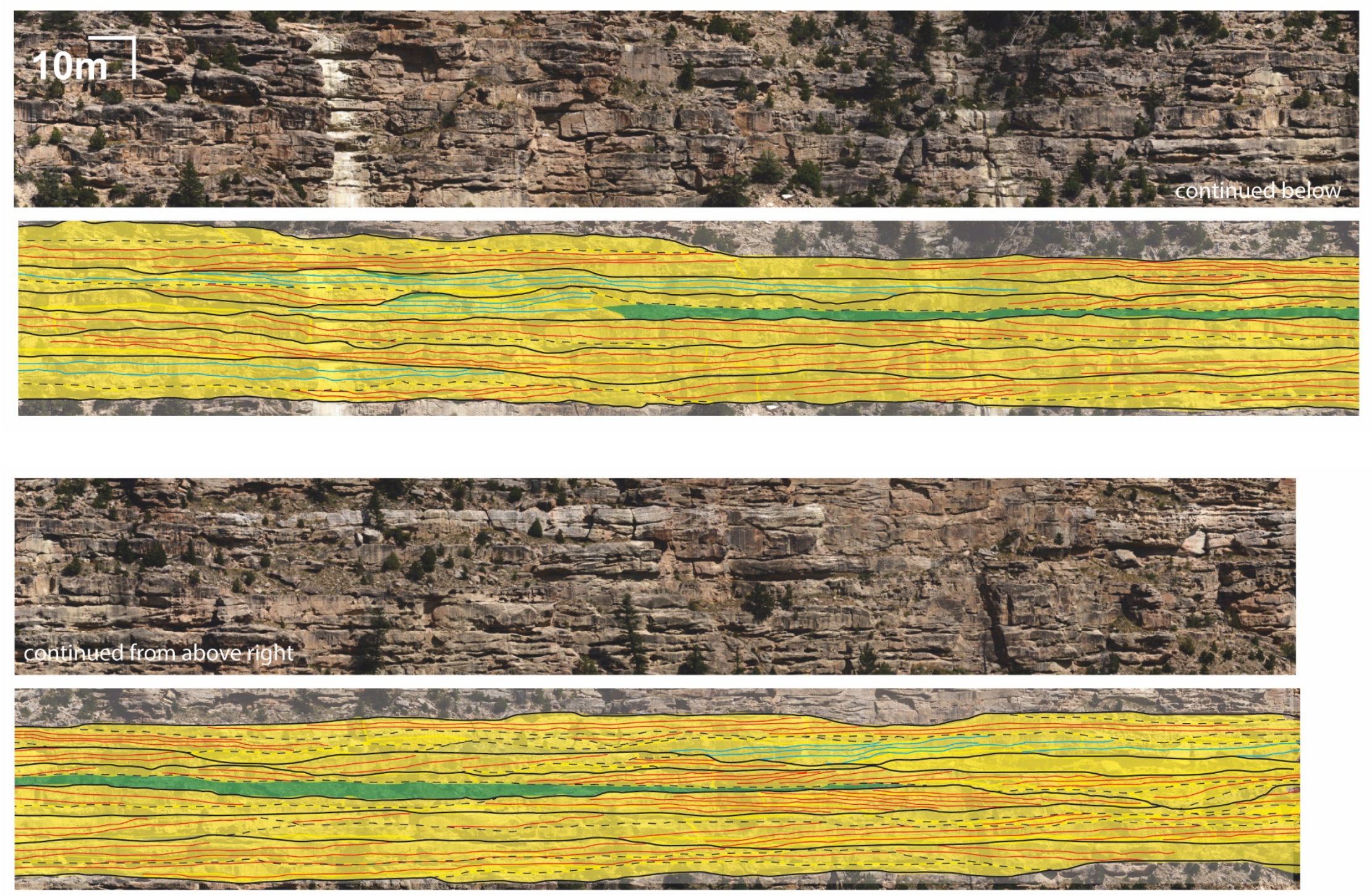

Figure DR3: Enlarged panel of lithofacies and bar preservation from Joe's Valley. The panel is oriented north-south (Figure DR1b). See manuscript Figure 2 for key and explanation. 


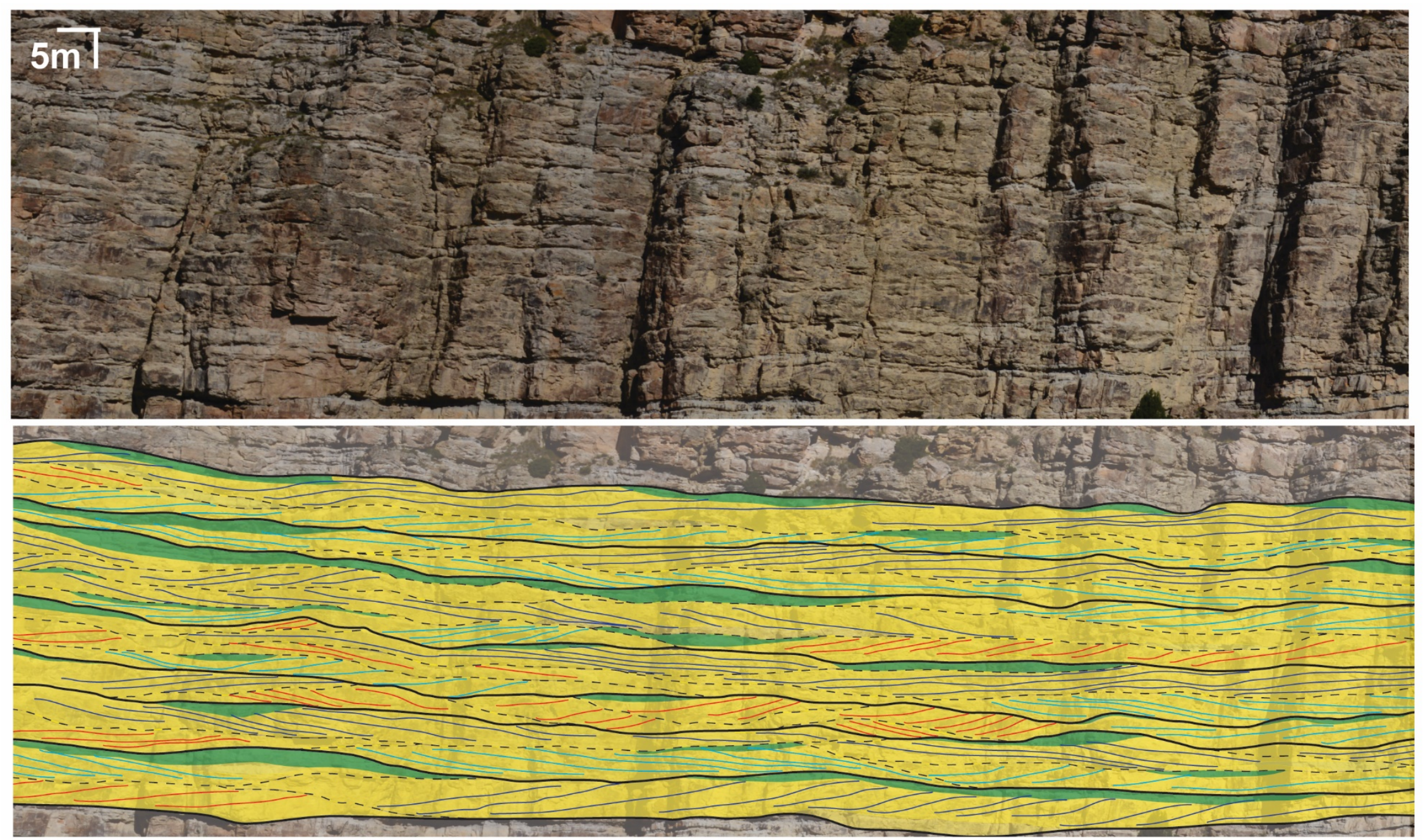

Figure DR4: Enlarged panel of bar preservation and lithofacies from Salina Canyon. The panel is oriented north-northeast-southsouthwest (Figure DR1c). See manuscript Figure 2 for key and explanation. 
Table DR1: Castlegate lithofacies summary.

Bar Normally graded upper medium to lower fine sandstone with $0.1-0.5 \mathrm{~m}$ thick trough cross-stratification sets and soft sediment deformation. Bedsets have sharp bases with some mud rip-up clasts. Many bar packages contain pockets of organic-rich, rippled, thinly bedded very fine sand at the bar toes. Lenses of upper medium trough cross-stratified thalweg deposits are present but rare.

Bar top Heavily rippled very fine sandstone gradational with underlying bar facies. Occasionally grades upward into massive gray siltstone. Lithofacies is up to $1.5 \mathrm{~m}$ thick with $0.1-0.5 \mathrm{~m}$ thick beds. Organicrich laminae are abundant.

\footnotetext{
Overbank and abandonment

Thinly bedded to massive gray siltstone and very fine lower sandstone with abundant organic material and limited paleosol development.
}

\section{Joe's Valley}

Upper fine sandstone to granules with 0.1-1m thick trough cross-stratification sets and highly amalgmated beds. Beds (0.2-0.5m thick) with very coarse sand to pebble bases commonly grade upward into upper fine sand. Beds have sharp bases with common gray/white silt rip-up clasts. Lenses of fine lower sand at bar toes are rare.

$0.2-0.6 \mathrm{~m}$ thick beds of upper very fine to lower medium sandstone containing less than $0.1 \mathrm{~m}$ thick sets of trough and tabular cross-stratification and current ripples. Beds are gradational with underlying bar lithofacies and are laterally discontinuous.

\section{Salina Canyon}

Lower fine to upper medium-grained sandstone with organized $0.1-0.75 \mathrm{~m}$ thick trough cross-stratification sets and some low-angle parallel laminations. Bedsets have sharp bases with rare granule lenses, and some contain soft sediment deformation. At the toes of some bar packages, there are centimeter- to decimeter-scale lenses of silt to lower fine sandstone with climbing and current ripples, parallel laminae, and organic matter drapes.

Decimeter- to meter-scale very fine lower to fine lower, thinly bedded, rippled sandstone with interbeds of gray siltstone. Sandstone interbeds are $0.1-0.5 \mathrm{~m}$ thick with small-scale current ripples, some climbing ripples, organic laminae, parallel laminations, and soft sediment deformation, and are interbedded with 0.1-0.2m thick siltstone beds. Bedsets are gradational with underlying bar facies, and the upper contact ranges from gradational to truncated.

Thin (less than $0.2 \mathrm{~m}$ thick) lower very fine sand beds with ripples and root casts interbedded with laminated to massive dark gray mudstone.
Decimeter- to meter-scale laminated gray siltstone and interbedded very fine lower to very fine upper sandstone. Sandstone beds have vertical root traces and are massive to parallel laminated. These deposits have aggradational basal contacts and erosional upper contacts. 


\section{Time-equivalence of study sites}

The upper Campanian Castlegate Sandstone comprises three informal units within the Mesaverde Group: the amalgamated lower Castlegate Sandstone (the subject of this study), the heterolithic middle Castlegate, and the coarse-grained Bluecastle Tongue (Fouch et al., 1983; McLaurin and Steel, 2000). The age and correlation of the lower Castlegate Sandstone has been a subject of extensive study and debate. Our Price Canyon outcrop location is in the same cliff face as the type section at Castle Gate, where the stratigraphy of the lower interval as lower Castlegate Sandstone is universally agreed upon (McLaurin and Steel, 2000; Miall and Arush, 2001; Pattison, 2010; Robinson and Slingerland, 1998; Van Wagoner, 1995; Yoshida, 2000; Yoshida et al., 1996). At Joe's Valley, however, the age of the basal quartz sandstone interval is debated. Robinson and Slingerland (1998) used palynology, lithofacies observations, and paleocurrent indicators to correlate the quartz sandstone at Joe's Valley with the lower Castlegate Sandstone in Price Canyon. In contrast, Miall and Arush (2001) use sandstone petrography to correlate the Joe's Valley sandstone with the younger Bluecastle Tongue, the unit overlying the lower Castlegate. These authors suggest that the base-Bluecastle unconformity has removed all lower Castlegate-age deposition from Joe's Valley. Neither of these interpretations is definitive, but as Miall and Arush (2001) acknowledge, small differences in sandstone petrology may record variations in source terrane along the Wasatch Plateau, rather than chronostratigraphic differences. For that reason, we use Robinson and Slingerland (1998)'s correlation in this study, as it is based on more concrete palynological evidence and field observations. Finally, the subdivisions of the Castlegate Sandstone are not traceable to the Salina Canyon site in the southern Wasatch Plateau, but we follow previous authors in the assumption that the quartz-rich amalgamated unit directly overlying the Blackhawk Formation is the lower Castlegate Sandstone (Adams and Bhattacharya, 2005). Overall, then, the exact age-equivalence between the sites in this study is not confidently established. However, at each of these sites, we examined the amalgamated quartz arenite unit directly overlying the mud-dominated fluvial Blackhawk Formation; as such, the previously interpreted change from high to low accommodation-creation has been assumed at all three sites. 


\section{OBJECT-BASED MODEL DESIGN AND SETUP}

The model used in this study is a 2D rule-based model modified from Chamberlin and Hajek (2015); see that reference for more details on model parameters and behaviors. This simple model builds stratigraphy with rectangular "channel elements" and floodplain deposits that are placed into the model basin at each timestep according to a set of avulsion and aggradation rules for determining the channel element location and floodplain aggradation. In the "random avulsion" case, the channel element location is drawn from a uniform random distribution of locations across the model domain. In the "compensational avulsion" case, the channel element is placed at the lowest point in the model domain (if there are multiple points of the same elevation, the location is selected randomly from the lowest points), and every $10^{\text {th }}$ timestep is a randomly selected avulsion location.

Basin topography is updated at each timestep once an avulsion location is chosen. The channel height, or location along the y-axis, is determined as a function of the pre-existing topographic height plus the channel-element thickness minus the channel-element incision (where incision is a proportion of the channel thickness), and floodplain locations aggrade following an exponential decay function on each side of the channel element. Floodplain does not aggrade above the height of the active channel element. The total amount of channel vs. floodplain accumulation is set by the ratio of the channel element area to the floodplain deposit area per timestep. The channel element area is set by the channel dimensions and is constant throughout the model run; the floodplain deposit area is set by the floodplain aggradation rate and also can vary per timestep according to the pre-existing topography, because floodplain does not aggrade above the height of the active channel element. Together, the input ratio of channel and floodplain input and the channel incision determine the overall model aggradation rate (where high floodplain aggradation rates and low channel incision yields the highest model aggradation rate).

Over 100 s of timesteps, these topography and location rules generate model stratigraphy with channel objects that have measurable preservation (Figure DR5, DR6). To calculate channel element preservation, we categorized channel elements as well preserved or poorly preserved based on maximum vertical preservation (MVP; Figure DR5) and total area preserved (TA; Figure DR5). Well preserved channel elements have retained their original thickness at some point along their width and have at least $50 \%$ of the total area preserved. Remaining elements are categorized as poorly preserved. The "well preserved" model category is roughly analogous to both the fully preserved and partially preserved field categories, and the poorly preserved model category approximates the "poorly preserved" field classification.

The net-to-gross of the model output is the percent of the output area that is channel element (i.e., the percent sand). Sediment retention (the fraction of supplied sediment retained in the final cross-section) is the final output area divided by the sum of the floodplain and channel input areas, which ultimately acts as a measure of how much of the total sediment input is preserved in the model stratigraphy.

For all runs, channel elements are 2.6 model units high and 119 model units wide, in a model domain that is 50 times the channel element width (Figure DR6). Each run is 1000 timesteps, which generates thick enough output that the "outcrop analysis" window falls in the center of the stratigraphy and does not include either the first or last $10 \%$ of channel elements to allow for model spin-up time and to avoid fully preserved elements at the top of the model output. The exponent for the exponential decay of floodplain aggradation away from the channel is -0.005 for all runs. Table DR2 shows additional model input parameters and results for each run included in this study. 


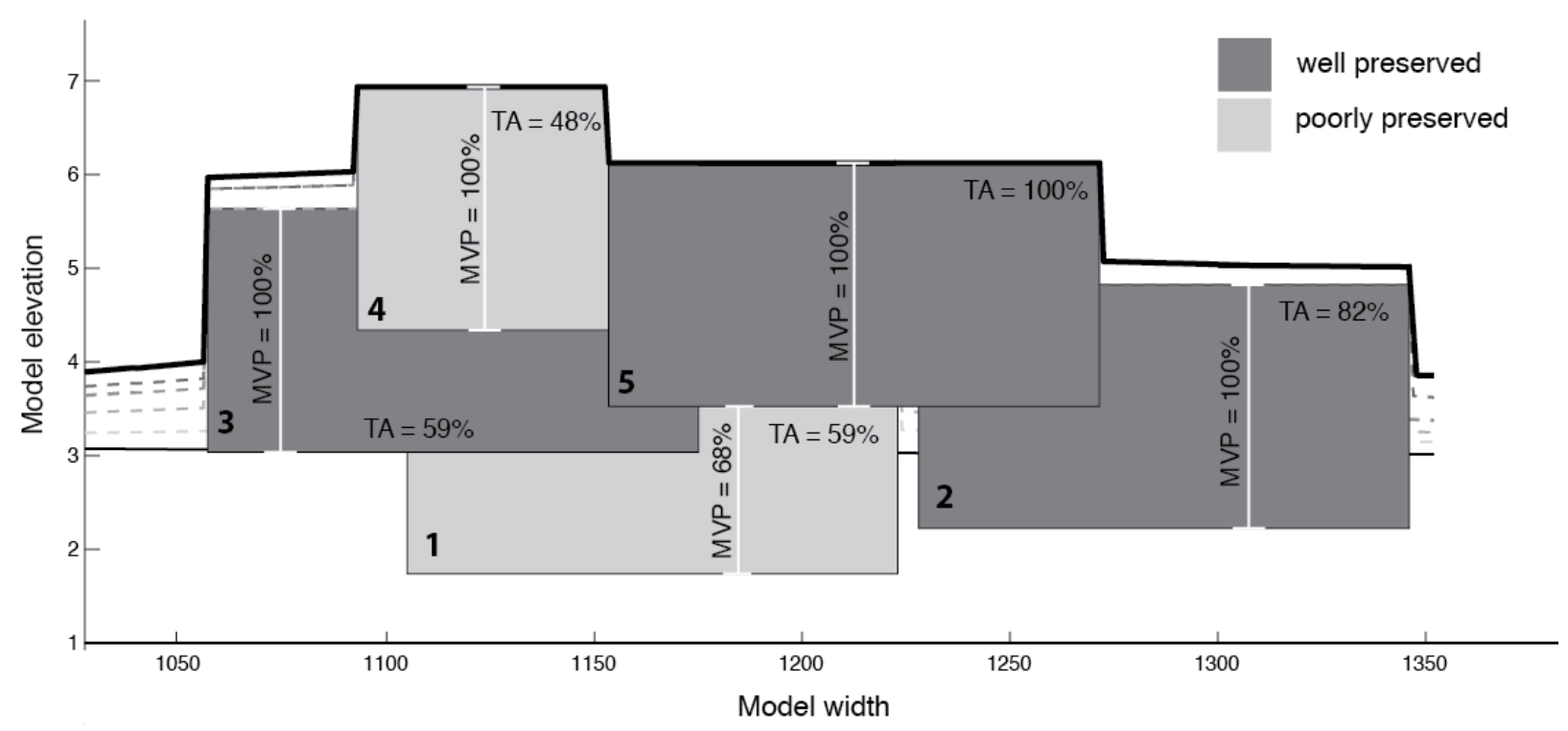

Figure DR5: Example 2D geometric model output for a random avulsion model run with a channel incision rate of $50 \%$ of the channel-element thickness and a floodplain aggradation rate of $12.5 \%$ of the channel-element thickness per timestep. Each rectangle is a channel element, and the numbers in the bottom left corner of each element indicate their relative age ( 1 being the oldest channel, 5 being the youngest). Elements with maximum vertical preservation (MVP) $>99 \%$ and total area (TA) $>50 \%$ are classified as well preserved (dark gray), while elements with MVP $<99 \%$ or TP $<50 \%$ are classified as poorly preserved (light gray). Dashed lines indicate floodplain topography at each timestep, and the bold black line indicates the final topography.

Figure DR6 (next pages): Examples of avulsion model outputs for runs with a range of bar preservations for random (A-B) and compensational (C-D) avulsions, including a full model output (top) and zoomed in model output of a subsection of the same run (bottom) for each example. Colors represent timestep from oldest (dark) to youngest (light). Black lines show topography for each timestep. In (A) top, the black rectangle delineates an area analogous to an outcrop-sized window within which the channel element preservation is analyzed. 
A. Random avulsion model output with high bar preservation (run 3 in Table DR2)
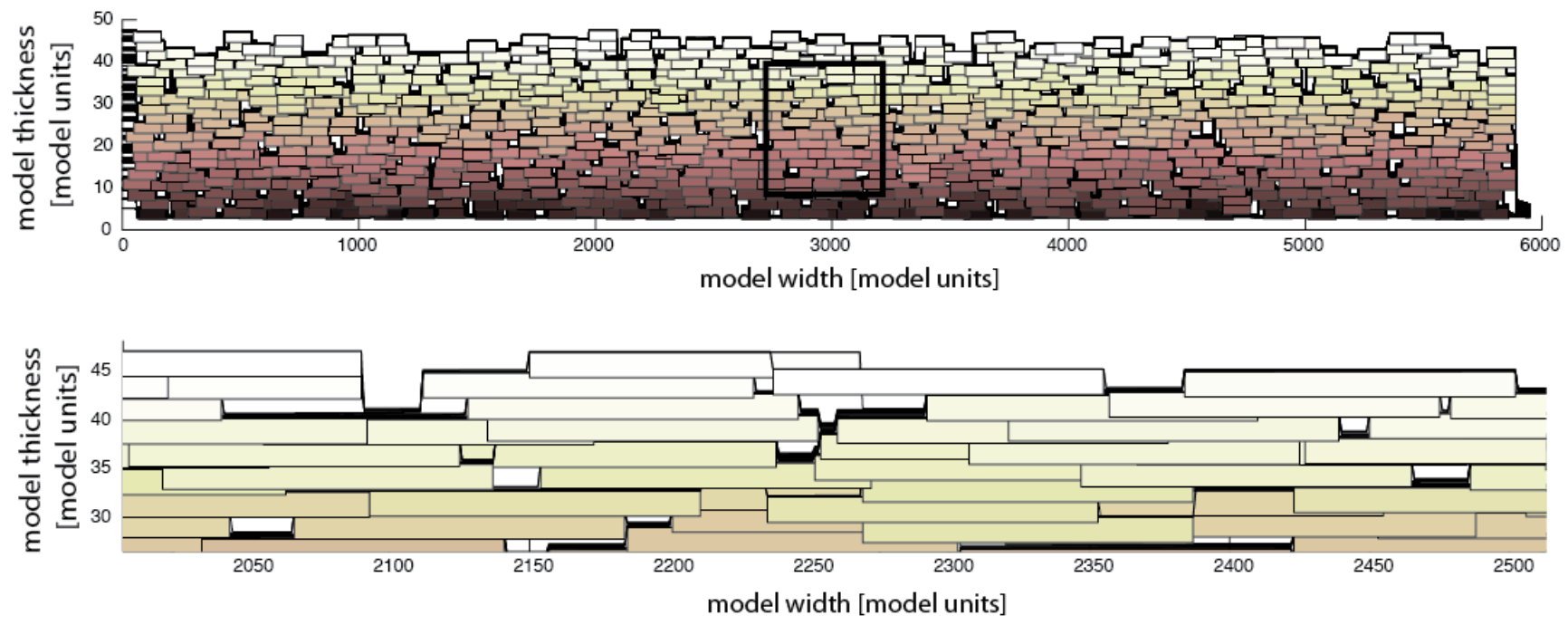

B. Random avulsion model output with low bar preservation (run 33 in Table DR2)
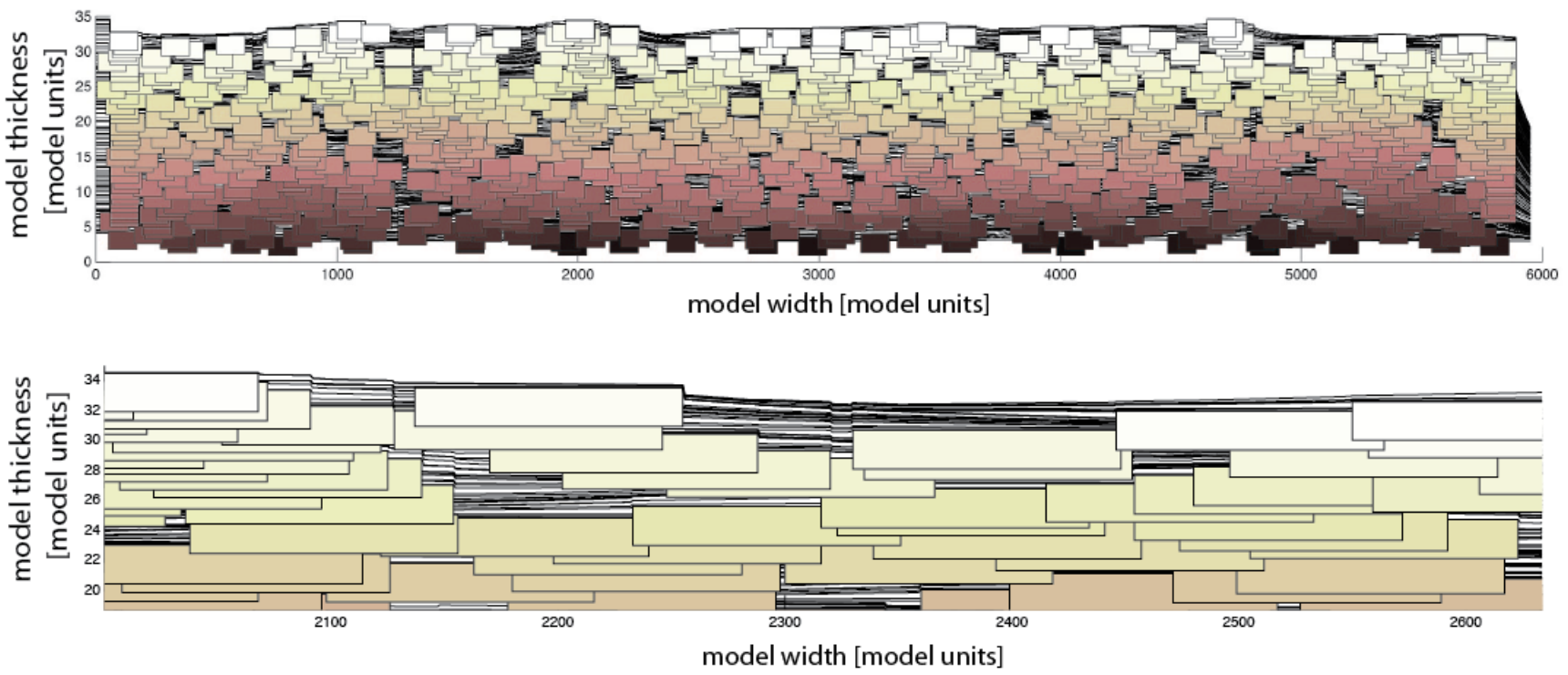
C. Compensational avulsion model output with high bar preservation (run 2 in Table DR2)
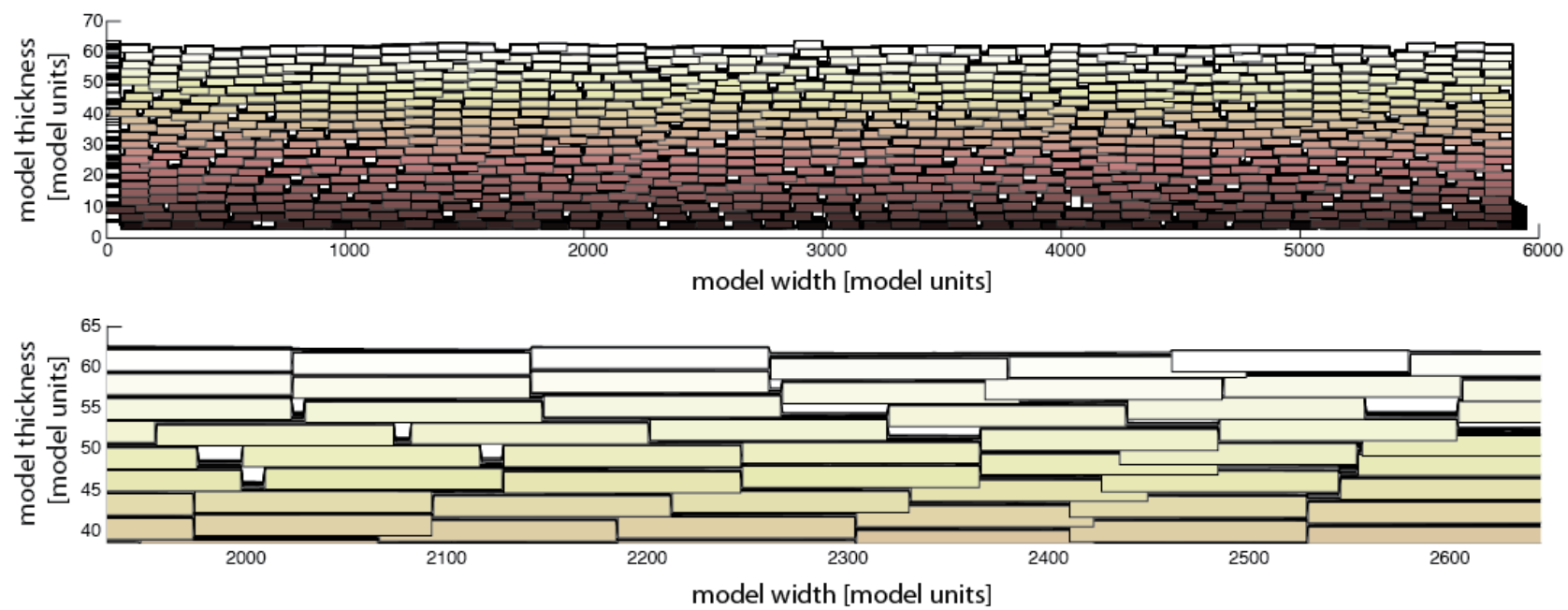

D. Compensational avulsion model output with low bar preservation (run 35 in Table DR2)

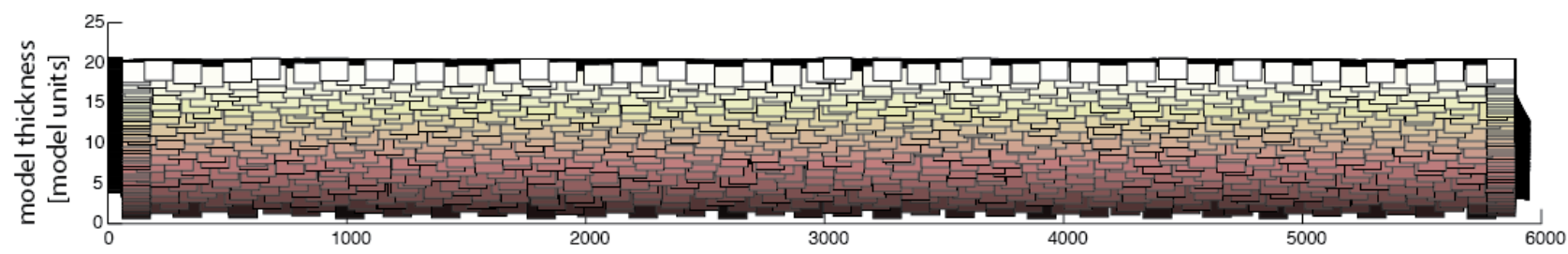

model width [model units]

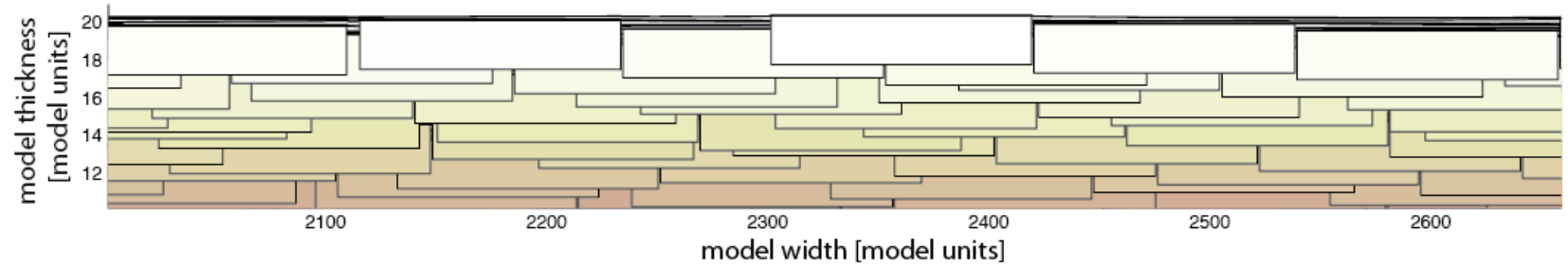


Table DR2: Input parameters and results for model runs in this study. See text for variable descriptions.

\begin{tabular}{|c|c|c|c|c|c|c|c|}
\hline $\begin{array}{c}\text { Run } \\
\# \\
\end{array}$ & $\begin{array}{c}\text { Incision rate } \\
{[\% \text { channel }} \\
\text { depth }]\end{array}$ & $\begin{array}{c}\text { Floodplain } \\
\text { aggradation } \\
\text { [model units] }\end{array}$ & $\begin{array}{c}\text { Ratio of } \\
\text { overbank to } \\
\text { channel input }\end{array}$ & $\begin{array}{c}\text { Well } \\
\text { preserved } \\
\text { bars [\%] }\end{array}$ & $\begin{array}{c}\text { Poorly } \\
\text { preserved } \\
\text { bars [\%] }\end{array}$ & $\begin{array}{l}\text { Net-to-gross } \\
{[\% \text { sand in }} \\
\text { model output }]\end{array}$ & $\begin{array}{c}\text { Sediment } \\
\text { retention } \\
{[\%]}\end{array}$ \\
\hline \multicolumn{8}{|c|}{ Random avulsion pattern } \\
\hline 1 & 10 & 0.1 & 0.09 & 65.0 & 35.0 & 84.8 & 86.4 \\
\hline 2 & 10 & 0.2 & 0.19 & 88.6 & 11.4 & 85.7 & 89.4 \\
\hline 3 & 20 & 0.1 & 0.09 & 52.1 & 47.9 & 94.8 & 79.4 \\
\hline 4 & 20 & 0.2 & 0.18 & 60.0 & 40.0 & 89.8 & 83.5 \\
\hline 5 & 20 & 0.3 & 0.28 & 93.9 & 6.1 & 83.1 & 85.8 \\
\hline 6 & 30 & 0.1 & 0.09 & 54.3 & 45.7 & 91.8 & 72.8 \\
\hline 7 & 30 & 0.2 & 0.18 & 66.7 & 33.3 & 87.7 & 76.8 \\
\hline 8 & 30 & 0.3 & 0.27 & 73.8 & 26.2 & 85.4 & 79.3 \\
\hline 9 & 30 & 0.4 & 0.36 & 78.1 & 21.9 & 80.4 & 81.0 \\
\hline 10 & 40 & 0.1 & 0.09 & 40.8 & 59.2 & 95.9 & 66.3 \\
\hline 11 & 40 & 0.1 & 0.17 & 62.5 & 37.5 & 88.9 & 69.4 \\
\hline 12 & 40 & 0.2 & 0.27 & 78.6 & 21.4 & 85.1 & 72.6 \\
\hline 13 & 50 & 0.3 & 0.08 & 32.8 & 67.2 & 97.2 & 57.9 \\
\hline 14 & 50 & 0.1 & 0.17 & 46.7 & 53.3 & 92.4 & 61.8 \\
\hline 15 & 50 & 0.2 & 0.27 & 61.5 & 38.5 & 88.5 & 65.2 \\
\hline 16 & 50 & 0.3 & 0.36 & 71.1 & 28.9 & 82.4 & 67.8 \\
\hline 17 & 50 & 0.4 & 0.47 & 78.4 & 21.6 & 80.6 & 70.4 \\
\hline 18 & 60 & 0.5 & 0.08 & 33.9 & 66.1 & 91.5 & 49.3 \\
\hline 19 & 60 & 0.1 & 0.17 & 26.8 & 73.2 & 89.0 & 53.8 \\
\hline 20 & 60 & 0.2 & 0.27 & 48.0 & 52.0 & 82.6 & 58.1 \\
\hline 21 & 60 & 0.3 & 0.37 & 45.3 & 54.7 & 90.1 & 61.0 \\
\hline 22 & 60 & 0.4 & 0.48 & 56.8 & 43.2 & 81.1 & 64.1 \\
\hline 23 & 70 & 0.5 & 0.08 & 17.7 & 82.3 & 98.4 & 41.6 \\
\hline 24 & 70 & 0.1 & 0.18 & 21.1 & 78.9 & 96.9 & 45.9 \\
\hline 25 & 70 & 0.2 & 0.28 & 31.7 & 68.3 & 92.4 & 50.5 \\
\hline 26 & 70 & 0.3 & 0.38 & 46.7 & 53.3 & 83.9 & 54.4 \\
\hline 27 & 70 & 0.4 & 0.48 & 72.7 & 27.3 & 81.7 & 57.5 \\
\hline 28 & 70 & 0.5 & 0.59 & 72.5 & 27.5 & 80.7 & 60.5 \\
\hline 29 & 70 & 0.6 & 0.68 & 46.9 & 53.1 & 80.4 & 62.7 \\
\hline 30 & 80 & 0.7 & 0.08 & 5.3 & 94.7 & 98.0 & 32.2 \\
\hline 31 & 80 & 0.1 & 0.18 & 12.9 & 87.1 & 95.2 & 37.9 \\
\hline 32 & 80 & 0.2 & 0.29 & 19.7 & 80.3 & 94.8 & 42.8 \\
\hline 33 & 80 & 0.3 & 0.38 & 42.1 & 57.9 & 87.9 & 46.6 \\
\hline 34 & 80 & 0.4 & 0.47 & 50.9 & 49.1 & 89.3 & 50.0 \\
\hline 35 & 80 & 0.5 & 0.56 & 48.0 & 52.0 & 87.2 & 53.0 \\
\hline 36 & 80 & 0.6 & 0.69 & 57.9 & 42.1 & 82.2 & 56.9 \\
\hline 37 & 90 & 0.8 & 0.09 & 3.6 & 96.4 & 94.0 & 22.8 \\
\hline
\end{tabular}




\begin{tabular}{|c|c|c|c|c|c|c|c|}
\hline $\begin{array}{c}\text { Run } \\
\# \\
\end{array}$ & $\begin{array}{c}\text { Incision rate } \\
{[\% \text { channel }} \\
\text { depth }]\end{array}$ & $\begin{array}{c}\text { Floodplain } \\
\text { aggradation } \\
\text { [model units] }\end{array}$ & $\begin{array}{c}\text { Ratio of } \\
\text { overbank to } \\
\text { channel input }\end{array}$ & $\begin{array}{c}\text { Well } \\
\text { preserved } \\
\text { bars [\%] }\end{array}$ & $\begin{array}{c}\text { Poorly } \\
\text { preserved } \\
\text { bars [\%] }\end{array}$ & $\begin{array}{l}\text { Net-to-gross } \\
\text { [\% sand in } \\
\text { model output] }\end{array}$ & $\begin{array}{c}\text { Sediment } \\
\text { retention } \\
{[\%]}\end{array}$ \\
\hline \multicolumn{8}{|c|}{$\underline{\text { Random avulsion pattern continued }}$} \\
\hline 38 & 90 & 0.1 & 0.18 & 7.7 & 92.3 & 92.6 & 29.4 \\
\hline 39 & 90 & 0.2 & 0.26 & 16.1 & 83.9 & 95.0 & 34.0 \\
\hline 40 & 90 & 0.3 & 0.34 & 33.3 & 66.7 & 86.7 & 37.8 \\
\hline 41 & 90 & 0.4 & 0.39 & 47.1 & 52.9 & 89.1 & 39.9 \\
\hline \multicolumn{8}{|c|}{ Compensational avulsion pattern } \\
\hline 1 & 10 & 0.1 & 0.11 & 97.1 & 2.9 & 91.7 & 97.3 \\
\hline 2 & 10 & 0.2 & 0.23 & 100.0 & 0.0 & 89.0 & 97.5 \\
\hline 3 & 20 & 0.1 & 0.11 & 43.9 & 56.1 & 98.0 & 87.9 \\
\hline 4 & 20 & 0.2 & 0.22 & 100.0 & 0.0 & 86.6 & 90.0 \\
\hline 5 & 20 & 0.3 & 0.34 & 100.0 & 0.0 & 80.1 & 90.8 \\
\hline 6 & 30 & 0.1 & 0.11 & 55.8 & 44.2 & 94.7 & 80.7 \\
\hline 7 & 30 & 0.2 & 0.23 & 61.0 & 39.0 & 94.1 & 81.2 \\
\hline 8 & 30 & 0.3 & 0.34 & 97.1 & 2.9 & 87.2 & 83.0 \\
\hline 9 & 40 & 0.1 & 0.11 & 66.0 & 34.0 & 92.9 & 70.2 \\
\hline 10 & 40 & 0.2 & 0.23 & 66.7 & 33.3 & 95.9 & 73.2 \\
\hline 11 & 40 & 0.3 & 0.34 & 89.2 & 10.8 & 92.9 & 75.4 \\
\hline 12 & 40 & 0.4 & 0.46 & 100.0 & 0.0 & 87.5 & 77.1 \\
\hline 13 & 50 & 0.1 & 0.11 & 54.4 & 45.6 & 99.2 & 61.1 \\
\hline 14 & 50 & 0.2 & 0.23 & 60.8 & 39.2 & 97.4 & 65.0 \\
\hline 15 & 50 & 0.3 & 0.34 & 69.2 & 30.8 & 96.7 & 67.7 \\
\hline 16 & 50 & 0.4 & 0.46 & 94.4 & 5.6 & 92.5 & 70.2 \\
\hline 17 & 50 & 0.5 & 0.58 & 100.0 & 0.0 & 85.3 & 72.4 \\
\hline 18 & 60 & 0.1 & 0.11 & 40.4 & 59.6 & 98.2 & 51.9 \\
\hline 19 & 60 & 0.2 & 0.23 & 62.5 & 37.5 & 97.8 & 56.4 \\
\hline 20 & 60 & 0.3 & 0.34 & 57.1 & 42.9 & 96.7 & 60.3 \\
\hline 21 & 60 & 0.4 & 0.46 & 66.7 & 33.3 & 93.7 & 63.4 \\
\hline 22 & 60 & 0.5 & 0.58 & 100.0 & 0.0 & 88.5 & 66.3 \\
\hline 23 & 70 & 0.1 & 0.11 & 16.4 & 83.6 & 99.0 & 42.9 \\
\hline 24 & 70 & 0.2 & 0.23 & 35.0 & 65.0 & 98.3 & 48.0 \\
\hline 25 & 70 & 0.3 & 0.35 & 70.4 & 29.6 & 98.3 & 52.7 \\
\hline 26 & 70 & 0.4 & 0.46 & 86.4 & 13.6 & 94.8 & 56.7 \\
\hline 27 & 70 & 0.5 & 0.58 & 92.3 & 7.7 & 89.2 & 59.9 \\
\hline 28 & 70 & 0.6 & 0.70 & 100.0 & 0.0 & 85.9 & 62.8 \\
\hline 29 & 80 & 0.1 & 0.11 & 5.3 & 94.7 & 99.0 & 33.7 \\
\hline 30 & 80 & 0.2 & 0.23 & 20.8 & 79.2 & 97.3 & 40.1 \\
\hline 31 & 80 & 0.3 & 0.35 & 45.0 & 55.0 & 97.9 & 45.4 \\
\hline 32 & 80 & 0.4 & 0.47 & 74.0 & 26.0 & 96.2 & 49.9 \\
\hline 33 & 80 & 0.5 & 0.58 & 83.7 & 16.3 & 84.4 & 53.6 \\
\hline
\end{tabular}




\begin{tabular}{cccccccc}
\hline \hline $\begin{array}{c}\text { Run } \\
\#\end{array}$ & $\begin{array}{c}\text { Incision rate } \\
\text { [\% channel } \\
\text { depth] }\end{array}$ & $\begin{array}{c}\text { Floodplain } \\
\text { aggradation } \\
\text { [model units] }\end{array}$ & $\begin{array}{c}\text { Ratio of } \\
\text { overbank to } \\
\text { channel input }\end{array}$ & $\begin{array}{c}\text { Well } \\
\text { preserved } \\
\text { bars [\%] }\end{array}$ & $\begin{array}{c}\text { Poorly } \\
\text { preserved } \\
\text { bars [\%] }\end{array}$ & $\begin{array}{c}\text { Net-to-gross } \\
\text { [\% sand in } \\
\text { model output] }\end{array}$ & $\begin{array}{c}\text { Sediment } \\
\text { retention } \\
{[\%]}\end{array}$ \\
\multicolumn{2}{l}{ Compensational avulsion pattern continued } \\
34 & 90 & 0.1 & 0.11 & 5.2 & 94.8 & 98.4 & 24.6 \\
35 & 90 & 0.2 & 0.23 & 5.5 & 94.5 & 98.7 & 32.0 \\
36 & 90 & 0.3 & 0.33 & 26.9 & 73.1 & 90.2 & 37.3 \\
37 & 90 & 0.4 & 0.40 & 31.1 & 68.9 & 80.3 & 40.3
\end{tabular}




\section{REFERENCES}

Adams, M. M., and Bhattacharya, J. P., 2005, No Change in Fluvial Style Across a Sequence Boundary, Cretaceous Blackhawk and Castlegate Formations of Central Utah, U.S.A: Journal of Sedimentary Research, v. 75, no. 6, p. 1038-1051.

Chamberlin, E. P., 2016, Using stratigraphic architecture to isolate the role of avulsion processes in alluvial-basin filling [Ph.D.: The Pennsyvlania State University, 246 p.

Chamberlin, E. P., and Hajek, E. A., 2015, Interpreting Paleo-Avulsion Dynamics from Multistory Sand Bodies: Journal of Sedimentary Research, v. 85, no. 2, p. 82-94.

Fouch, T. D., Lawton, T. F., Nichols, D. J., Cashion, W. B., and Cobban, W. A., 1983, Patterns and timing of synorogenic sedimentation in Upper Cretaceous rocks of central and northeast Utah, in Reynolds, M. W., and Dolly, E. D., eds., Mesozoic Paleogeography of the West-Central United States: Denver, Rocky Mountain Section Society of Economic Paleontologists and Mineralogists, p. 305-336.

McLaurin, B. T., and Steel, R., 2000, Fourth-order nonmarine to marine sequences, middle Castlegate Formation, Book Cliffs, Utah: Geology, v. 28, no. 4, p. 359-362.

Miall, A., 2014, The Emptiness of the Stratigraphic Record: A Preliminary Evaluation of Missing Time In the Mesaverde Group, Book Cliffs, Utah, U.S.A: Journal of Sedimentary Research, v. 84, no. 6, p. 457-469.

Miall, A., and Arush, M., 2001, The Castlegate Sandstone of the Book Cliffs, Utah: Sequence Stratigraphy, Paleogeography, and Tectonic Controls: Journal of Sedimentary Research, v. 71, no. 4, p. 537-548.

Pattison, S., 2010, Alternative sequence stratigraphic model for the Desert Member to Castlegate Sandstone interval, Book Cliffs, eastern Utah: Implications for the high-resolution correlation of falling stage nonmarine, marginal-marine, and marine strata, in Morgan, L. A., and Quane, S. L., eds., Through the Generations: Geologic and Anthropogenic Field Exercusions in the Rocky Mountains from Modern to Ancient: Geological Society of America Field Guide 18, p. 163-192.

Robinson, R. A. J., and Slingerland, R. L., 1998, Grain-size trends, basin subsidence and sediment supply in the Campanian Castlegate Sandstone and equivalent conglomerates of central Utah: Basin Research, v. 10, p. 109-127.

Van Wagoner, J. C., 1995, Sequence stratigraphy and marine to nonmarine facies architecture of foreland basin strata, Book Cliffs, Utah, U.S.A., in Van Wagoner, J. C., and Bertram, G. T., eds., Sequence Stratigraphy of Foreland Basin Deposits: Outcrop and Subsurface Examples from Cretaceous of North America, American Association of Petroleum Geologists, Memoir 64, p. 137-223.

Yoshida, S., 2000, Sequence and facies architecture of the upper Blackhawk Formation and the Lower Castlegate Sandstone (Upper Cretaceous), Book Cliffs, Utah, USA: Sedimentary Geology, p. 239-276.

Yoshida, S., Willis, A., and Miall, A., 1996, Tectonic Control of Nested Sequence Architecture in the Castlegate Sandstone (Upper Cretaceous), Book Cliffs, Utah: Journal of Sedimentary Research, v. 66, no. 4, p. 737-748. 